\title{
The diagnostic values of procalcitonin and interleukin 6 in acute appendicitis
}

\author{
Alireza Rastgoo Haghi ${ }^{1}$, Amir Kasraianfard ${ }^{2}$, Alireza Monsef ${ }^{1}$, Amin Shoa Kazemi ${ }^{1}$, Siavash Rahimi ${ }^{3}$, Seyed Mohammad Reza Javadi ${ }^{2}$ \\ ${ }^{1}$ Department of Pathology, Hamadan University of Medical Sciences, Hamadan, Iran \\ ${ }^{2}$ Department of Surgery, Hamadan University of Medical Sciences, Hamadan, Iran \\ ${ }^{3}$ Department of Internal Medicine, Mazandaran University of Medical Sciences Ramsar Campus, Sari, Iran
}

\begin{abstract}
Objective: Despite the recent use of computed tomography scan and diagnostic laparoscopy, acute appendicitis is still highly misdiagnosed. Timely diagnosis of acute appendicitis is more crucial in children and elderly patients because of vague symptoms and rapid progression to perforation in these age groups, which may result in high rates of morbidity and mortality. The aim of the present study was to find the diagnostic values of procalcitonin and interleukin 6 (IL-6) for diagnosing acute appendicitis in our center.

Material and Methods: Patients who were suspected of acute appendicitis and referred to the emergency department of a tertiary care urban hospital in 2016 were enrolled in the study. A $5 \mathrm{~mL}$ blood sample was obtained from each patient before appendectomy and was examined for procalcitonin and IL-6. Then the resected specimen of the appendix was studied by a pathologist, and a definite diagnosis was made.

Results: Eighty patients including $53(66.3 \%)$ men who underwent appendectomy were enrolled in the study. The diagnosis of acute appendicitis was histopathologically confirmed in 60 (75\%) patients including 18,20, and 22 patients with inflammatory, suppurative, and gangrenous/perforated appendicitis, respectively. The sensitivity and specificity of procalcitonin versus IL-6 for diagnosing acute appendicitis were $65 \%$ and $80 \%$ vs. $76 \%$ and $55 \%$, respectively. The sensitivity and specificity of concurrent procalcitonin and IL-6 for diagnosing acute appendicitis were $95 \%$ and $55 \%$, respectively. Conclusion: Our study suggests that parallel measurement of procalcitonin and IL- 6 decreases unnecessary negative appendectomies.
\end{abstract}

Keywords: Appendicitis, interleukin 6, procalcitonin

Cite this article as: Rastgoo Haghi A, Kasraianfard A, Monsef A, Kazemi AS, Rahimi S, Javadi SMR. The diagnostic values of procalcitonin and interleukin 6 in acute appendicitis. Turk J Surg 2019; 35 (1): 19-22

\section{Corresponding Author}

Seyed Mohammad Reza Javadi

E-mail: smrezajavadi@gmail.com

Received: 02.02 .2018

Accepted: 19.03 .2018

Available Online Date: 20.11 .2018

o Copyright 2019 by Turkish Surgical Society Available online at www.turkjsurg.com

DOI: 10.5578/turkjsurg.4113

\section{INTRODUCTION}

Appendicitis is the most common cause of surgery of the abdomen with an incidence rate of 11 in 10.000 annually, and it most commonly occurs in the second to fourth decade of life especially in young adults $(1,2)$. Timely diagnosis of acute appendicitis is crucial especially in children and elderly patients because of vague symptoms and rapid progression to perforation in these age groups, which may result in high rates of complications including wound infection, intra-abdominal abscess formation, and mortality (3,4). Despite the recent use of computed tomography scan and diagnostic laparoscopy, acute appendicitis is still highly misdiagnosed at a rate of 15\%, with the highest number of negative appendectomy seen in elderly women (5). Hence, additional preoperative testing may be helpful for the timely diagnosis of acute appendicitis. Although the role of the measurement of inflammatory cytokines, such as procalcitonin, interleukin 6 (IL-6), and C-reactive protein, which are involved in acute and chronic inflammatory responses in addition to the measurement of white cell count and bilirubin for diagnosing acute appendicitis, has been investigated in few studies, the results have varied with no consensus about the best test $(6,7)$.

The aim of the present study was to find the diagnostic values of procalcitonin and $\mathrm{IL}-6$ in the diagnosis of acute appendicitis and their associations with the severity of the disease in our center. 


\section{MATERIAL and METHODS}

\section{Patient Selection}

In this prospective study, patients who were suspected of acute appendicitis and referred to the emergency department of a tertiary care urban hospital in 2016 were enrolled in the study. Patients with an Alvarado score of $>5$ or in whom diagnosis of acute appendicitis was documented using computed tomography scan were included into the study. Exclusion criteria comprised patients with a history of autoimmune disease; who underwent transplantation; receiving immunosuppressive, antibiotic, and/or immunomodulator drugs; who were in sepsis; or who were markedly overweight with a body mass index $>25$. All patients were visited and examined by the same surgeon.

The research was conducted according to the principles of the World Medical Association Declaration of Helsinki “Ethical Principles for Medical Research Involving Human Subjects" (amended in October 2013). Written informed consent was obtained from all participants. Medical University Ethics Committee approved the study.

\section{Study Protocol}

A $5 \mathrm{~mL}$ blood sample was obtained from each patient before appendectomy. No antibiotic or antipyretic drugs were administered before sampling. Serum samples were stored at $-20^{\circ} \mathrm{C}$, and all measurements were performed under similar conditions on the same day. The measurement of procalcitonin and IL-6 was performed using enzyme-linked immunosorbent assay Human Procalcitonin (Eastbiopharm, China) and AviBion Human IL-6 (Orgenium, Finland) kits, respectively. Serum levels of $>0.5 \mathrm{ng} / \mathrm{mL}$ for procalcitonin and $5 \mathrm{pg} / \mathrm{mL}$ for IL-6 were considered as positive in our study. A pathologist examined the resected specimen of the appendix, and a definite diagnosis was made as normal appendix, inflammatory defined as infiltration of inflammatory cells, suppurative defined as infiltration of inflammatory cells with destruction of the appendiceal wall, with no evidence of abscess or perforation, and gangrenous and/or perforated appendicitis defined as infiltration of inflammatory cells, necrotic appendiceal wall, and macroscopic periappendiceal abscess and/or perforation.

\section{Statistical Analyses}

Data were analyzed using the Statistical Package for the Social Sciences (SPSS) version 20.0 (IBM Corp., Armonk, NY, USA). Qualitative and quantitative data were compared using the Fischer's exact and independent $t$ tests, respectively. A p value $<0.05$ was considered as statistically significant.

\section{RESULTS}

Eighty patients including 53 (66.3\%) men who underwent appendectomy were enrolled in the study. The frequency of patients in the $0-20,21-40,41-60$, and older than 60 years old age groups were 30 (37.5\%), 39 (48.8\%), 6 (7.5\%), and 5 (6.2\%) patients, respectively. The diagnosis of acute appendicitis was histopathologically confirmed in 60 (75\%) patients including 18, 20, and 22 patients with inflammatory, suppurative, and gangrenous/perforated appendicitis, respectively.

Figure 1 shows the frequency of positive procalcitonin or IL-6 in patients with the aforementioned different histopathology diagnoses. The sensitivity and specificity of procalcitonin for diagnosing acute appendicitis were $65 \%$ and $80 \%$, respectively, with positive and negative likelihood ratios of 3.25 and 0.43 , respectively, and positive and negative predictive values of $90 \%$ and $43 \%$, respectively. In addition, the sensitivity and specificity of IL-6 for diagnosing acute appendicitis were $76 \%$ and 55\%, respectively, with positive and negative likelihood ratios of 1.7 and 0.42 , respectively, and positive and negative predictive values of $83 \%$ and $44 \%$, respectively. On the other hand, the sensitivity and

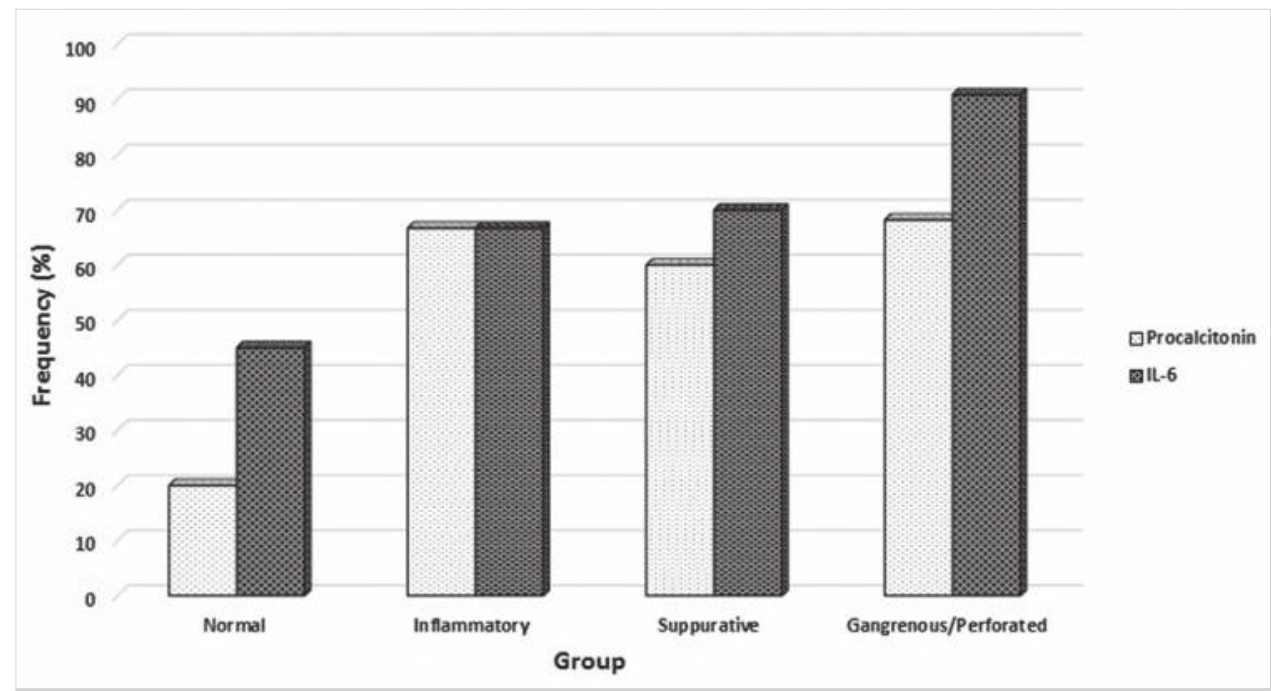

Figure 1. Frequency of positive procalcitonin or IL-6 in patients with different histopathology diagnoses. 
specificity of using concurrent procalcitonin and IL-6 together for diagnosing acute appendicitis were 95\% and 55\%, respectively.

\section{DISCUSSION}

Fecaliths or inflammatory hypertrophy of the lymph nodes is a major cause of proximal appendiceal lumen obstruction that may lead to impaired blood supply of the appendix followed by rapid multiplication of resident bacteria of the appendix and bacterial endotoxin release (8). Bacterial endotoxins, in addition to the proinflammatory cytokines, promote the release of procalcitonin as an early marker of systemic bacterial infection associated with the severity of the infection. Moreover, it has been proposed that the expression of calcitonin I gene, which is responsible for the production of procalcitonin, is highly increased during bacterial infection (9). On the other hand, the measurement of serum procalcitonin with a half-life of $24 \mathrm{~h}$ has been shown to be reproducible and affordable with a low time spent for obtaining the result, making it a reasonable choice for diagnosing acute appendicitis (10-12). In our study, the sensitivity and specificity of serum procalcitonin for diagnosing acute appendicitis were $65 \%$ and $80 \%$, respectively, and for diagnosing perforated appendicitis were 68\% and 52\%, respectively.

Similarly, in a recent systematic review by Acharya et al., the pooled sensitivity and specificity of procalcitonin for diagnosing acute appendicitis have been found as 36\% and 88\%, respectively, and for diagnosing perforated appendicitis as 69\% and $67 \%$, respectively (13). Similar to our results, some other studies have suggested that the measurement of procalcitonin is more sensitive for diagnosing perforated appendicitis, whereas it has less accuracy for diagnosing uncomplicated appendicitis $(14,15)$.

During acute appendicitis, other proinflammatory cytokines, especially IL-6 as mediators of fever and acute phase reactions, are secreted due to the inflammatory process and neutrophil recruitment following the invasion of bacteria to the appendix (16, 17). In the present study, the sensitivity and specificity of serum IL-6 for diagnosing acute appendicitis were 76\% and 55\%, respectively, and for diagnosing perforated appendicitis were $91 \%$ and $37 \%$, respectively. Similarly, previous studies have shown that the measurement of IL- 6 is associated with high sensitivity and low specificity for diagnosing acute appendicitis. Ozguner et al. have shown that the serum level of IL-6 is significantly lower in children with negative appendectomy than in children with complicated or uncomplicated appendicitis, suggesting that the measurement of $\mathrm{IL}-6$ is helpful in reducing the number of negative appendectomies (18).

In the study by Gürleyik et al., the sensitivity and specificity of IL-6 are $84 \%$ and 46\%, respectively, and a marked elevation of IL-6 level has been reported in patients with perforated appendicitis (19). In the aforementioned systematic review, similar to our study, the pooled sensitivity and specificity of IL-6 for diagnosing acute appendicitis have been found as $73 \%$ and $72 \%$, respectively, and for diagnosing perforated appendicitis as 79\% and $63 \%$, respectively. Moreover, the overall performance of IL-6 has been reported to be superior to procalcitonin, especially in terms of cost, sensitivity, and prediction of perforation.

However, IL-6 is not specific especially for diagnosing complicated appendicitis and associated with higher time spent for obtaining the result than procalcitonin (13). As previously mentioned, the measurement of procalcitonin was associated with low sensitivity and high specificity, whereas IL-6 was associated with high sensitivity and low specificity for the diagnosis of acute appendicitis. The total sensitivity and specificity of measurement of these two biomarkers combined were 95\% and 55\%, respectively, for diagnosing of acute appendicitis.

\section{CONCLUSION}

Our study suggests that the measurement of combining procalcitonin and IL-6 can provide beneficial evidence for superior decision-making, and owing to high sensitivity, negative results of each of these biomarkers may assist in ruling out acute appendicitis and reducing the number of negative appendectomies.

Ethics Committee Approval: Ethics committee approval was received for this study from the Ethics Committee of Hamadan University of Medical Sciences.

Informed Consent: Written informed consent was obtained from patients who participated in this study.

Peer-review: Externally peer-reviewed.

Author Contributions: Concept - A.R.H., S.M.R.J., A.M.; Design - A.R.H., S.M.R.J., A.S.K.; Supervision - A.R.H., A.K., S.M.R.J.; Resource - A.R.H., S.M.R.J., A.M.; Materials - A.R.H., A.K., A.M.; Data Collection and/or Processing - A.K., S.R., A.S.K.; Analysis and/or Interpretation - A.R.H., A.S.K., A.K.; Literature Search - S.M.R.J., A.M., A.K.; Writing Manuscript - A.K., S.R., A.S.K.; Critical Reviews A.R.H., S.M.R.J., A.M.

Conflict of Interest: The authors have no conflicts of interest to declare.

Financial Disclosure: The authors declared that this study has received no financial support.

\section{REFERENCES}

1. Singh A, Danrad R, Hahn PF, Blake MA, Mueller PR, Novelline RA. MR imaging of the acute abdomen and pelvis: acute appendicitis and beyond. Radiographics 2007;27:1419-31. [CrossRef]

2. Livingston EH, Woodward WA, Sarosi GA, Haley RW. Disconnect between incidence of nonperforated and perforated appendicitis: implications for pathophysiology and management. Ann Surg 2007;245:88692. [CrossRef]

3. Franz MG, Norman J, Fabri PJ. Increased morbidity of appendicitis with advancing age. Am Surg 1995;61:40-4.

4. Yamini D, Vargas H, Bongard F, Klein S, Stamos MJ. Perforated appendicitis: is it truly a surgical urgency? Am Surg 1998;64:970-5.

5. Flum DR, Morris A, Koepsell T, Dellinger EP. Has misdiagnosis of appendicitis decreased over time? A population-based analysis. Jama 2001;286:1748-53. [CrossRef] 
6. Abbas MH, Choudhry MN, Hamza N, Ali B, Amin AA, Ammori BJ. Admission levels of serum amyloid $a$ and procalcitonin are more predictive of the diagnosis of acute appendicitis compared with C-reactive protein. Surg Laparosc Endosc Percutan Tech 2014;24:488-94.[CrossRef]

7. Atahan K, Ureyen O, Aslan E, Deniz M, Cokmez A, Gur S, et al. Preoperative diagnostic role of hyperbilirubinaemia as a marker of appendix perforation. J Int Med Res 2011;39:609-18. [CrossRef]

8. Brunicardi FC, Andersen DK, Billiar TR, Dunn DL, Hunter JG. Schwartz's principles of surgery / editor-in-chief, F. Charles Brunicardi; associate editors, Dana K. Andersen, Timothy R. Billiar, David L. Dunn, John G. Hunter, Jeffrey B. Matthews, Raphael E. Pollock. 10 ${ }^{\text {th }}$ ed: McGraw-Hill Education; 2014

9. Muller B, White JC, Nylen ES, Snider RH, Becker KL, Habener JF. Ubiquitous expression of the calcitonin-i gene in multiple tissues in response to sepsis. J Clin Endocrinol Metab 2001;86:396-404. [CrossRef]

10. Chakhunashvili L, Inasaridze A, Svanidze S, Samkharadze J, Chkhaidze l. Procalcitonin as the biomarker of inflammation in diagnostics of pediatric appendicular peritonitis and for the prognosis of early postoperative complications. Georgian Med News 2005:129:78-81.

11. Jensen JU, Heslet L, Jensen TH, Espersen K, Steffensen P, Tvede M. Procalcitonin increase in early identification of critically ill patients at high risk of mortality. Crit Care Med 2006;34:2596-602. [CrossRef]

12. Chandel V, Batt SH, Bhat MY, Kawoosa NU, Yousuf A, Zargar BR. Procalcitonin as the biomarker of inflammation in diagnosis of appendicitis in pediatric patients and prevention of unnecessary appendectomies. Indian J Surg 2011:73:136-41. [CrossRef]
13. Acharya A, Markar SR, Ni M, Hanna GB. Biomarkers of acute appendicitis: systematic review and cost-benefit trade-off analysis. Surgical Endoscopy 2017;31:1022-31. [CrossRef]

14. Wu JY, Chen HC, Lee SH, Chan RC, Lee CC, Chang SS. Diagnostic role of procalcitonin in patients with suspected appendicitis. World J Surg 2012;36:1744-9. [CrossRef]

15. Yu CW, Juan LI, Wu MH, Shen CJ, Wu JY, Lee CC. Systematic review and meta-analysis of the diagnostic accuracy of procalcitonin, C-reactive protein and white blood cell count for suspected acute appendicitis. Br J Surg 2013;100:322-9. [CrossRef]

16. Gabay C, Kushner I. Acute-phase proteins and other systemic responses to inflammation. N Engl J Med 1999;340:448-54. [CrossRef]

17. Rivera-Chavez FA, Wheeler H, Lindberg G, Munford RS, O'Keefe GE. Regional and systemic cytokine responses to acute inflammation of the vermiform appendix. Ann Surg 2003;237:408-16. [CrossRef]

18. Ozguner I, Kizilgun M, Karaman A, Cavusoglu YH, Erdogan D, Karaman I, et al. Are neutrophil CD64 expression and interleukin-6 early useful markers for diagnosis of acute appendicitis? Eur J Pediatr Surg 2014;24:179-83.

19. Gurleyik G, Gurleyik E, Cetinkaya F, Unalmiser S. Serum interleukin-6 measurement in the diagnosis of acute appendicitis. ANZ J Surg 2002;72:665-7. [CrossRef]

\title{
Akut apandisit tanısında prokalsitonin ve interlökin 6 değeri
}

\author{
Alireza Rastgoo Haghi ${ }^{1}$, Amir Kasraianfard ${ }^{2}$, Alireza Monsef ${ }^{1}$, Amin Shoa Kazemi ${ }^{1}$, Siavash Rahimi ${ }^{3}$, Seyed Mohammad Reza Javadi ${ }^{2}$ \\ ${ }^{1}$ Hamadan Üniversitesi Tıp Bilimleri, Patoloji Bölümü, Hamadan, İran \\ ${ }^{2}$ Hamadan Üniversitesi Tıp Bilimleri, Cerrahi Bölümü, Hamadan, Iran \\ ${ }^{3}$ Mazandaran Üniversitesi Ramsar Kampüsü, İ̧̧ Hastalıkları Bölümü, Sari, Iran
}

\section{ÖZET}

Giriş ve Amaç: Son yıllarda artan bilgisayarlı tomografi ve tanısal laparoskopi kullanımına rağmen akut apandisit hala yüksek oranda yanlış tanı almaktadır. Bu yaş gruplarında belirsiz semptomlar ve perforasyona çabuk ilerlemesi sebebiyle yüksek oranda morbidite ve mortalite ile sonuçlanması, akut apandisit tanısının çocuklarda ve ileri yaşlı hastalarda zamanında konmasının öneminin altını çizmektedir. Bu çalışmanın amacı, merkezimizde akut apandisiti tanılamak için prokalsitonin ve interlökin 6 (IL-6) tanısal değerlerini ortaya koymaktır.

Gereç ve Yöntem: Çalışmaya, 2016 yılında akut apandisit şüphesi ile üçüncü basamak şehir hastanesi acil servisine sevk edilen hastalar dahil edilmiştir. Appendektomi öncesi bütün hastalardan $5 \mathrm{~mL}$ kan örneği alınarak prokalsitonin ve IL-6 incelemesi yapıldı. Daha sonra, apandisin kesip çıkarılan örneği bir patolojist tarafından incelendi ve kesin tanı konuldu.

Bulgular: Elli üç (\%66.3)'ü erkek olmak üzere appendektomi alan toplamda 80 hasta çalışmaya dahil edildi. Akut apandisitis tanısı $18^{\prime} \mathrm{i}$ inflamatuvar, 20'si süpüratif ve 22'si gangrenli/perfore apandis olmak üzere 60 (\%75) hastada histopatolojik olarak teyit edildi. Akut apandisit tanısında IL-6'ya karşın prokalsitonin duyarlıı̆̆ı ve özgüllüğü ardışık olarak \%80'e \%65 ve \%55'e \%76 olarak bulundu. Akut apandisit tanısı için eşzamanlı prokalsitonin ve IL-6 duyarlıık ve özgüllüğü ise ardışık olarak \%95 ve \%55 olarak tespit edildi.

Sonuç: Çalışmamız, gereksiz negatif appendektomilerinin prokalsitonin ve IL-6 paralel ölçümleri ile azaltılabileceğini göstermiştir.

Anahtar Kelimeler: Apandisit, interlökin 6, prokalsitonin

Doi: $10.5578 /$ turkjsurg.4113 